\title{
CHRISTIANS IN LATE PAGAN, AND PAGANS IN EARLY CHRISTIAN LITHUANIA: THE FOURTEENTH AND FIFTEENTH CENTURIES
}

\author{
Darius Baronas
}

ABSTRACT This paper deals with the issue of the presence of Christians and pagans in pagan (13th century to 1387) and early Christian Lithuania (from 1387 to the early 15th century). The author proposes to use a group-oriented approach to deal with the question of the political decisionmaking process of accepting or not accepting the Christian faith. It is his contention that the personal 'life style' preferences of individual dukes and their entourage were much more decisive than large-scale political calculations that have been given much attention by historians. This approach helps explain the incremental rise of Christianity within the ruling house, which carried the day when new rulers with a different mentality (Grand Duke Jogaila first) came to the helm of the state. The Christian presence was felt most in Vilnius, and to some degree also in Kernave. Their arrival (from Livonia and Rus') was encouraged by the pagan rulers of Lithuania to satisfy their need for a skilled workforce. The settlers certainly contributed to the final conversion of Lithuania initiated in 1387, by making the Christian influence a permanent factor and an attractive option. Pagans in Lithuania did not form a coherent religious group; that is why there was no opposition from them when the grand-ducal decision and the council of the boyars became the new rule of the land. Pagans could be encountered in Žemaitija in the early 15th century. Technically, they should be understood as non-baptised people. To treat as "pagan" those people who practised folk ways is problematic, as the excursus on the experiences of Jerome of Prague (c. 1369-c. 1440) shows. The general situation, even very close in the wake of the conversion, might be conceived as one of syncretism, which was the order of the day for people from the lower strata and living far away from churches for many centuries to come.

Today it is almost received wisdom to reiterate that medieval Lithuania was the last pagan state in Europe: the pagan population of Lithuania officially converted to the Roman Catholic faith as late as 1387, and the westernmost part of Lithuania, Žemaitija (also known in fiction and non-fiction as Samogitia), converted 600 
years ago, in $1413-1417 .{ }^{1}$ Quite a few Lithuanians are proud of this fact; however, it should be noted that, technically, the ancient Lithuanians were not the last pagans of Europe. In cold parts of present-day Finland, and in faraway places such as the approaches to the Ural mountains, pagan tribes could be encountered well into the early modern period. ${ }^{2}$ Perhaps much the same may apply to the peasants of early-modern Lithuania, who happened to live far away from the nearest parish church, and who were characterised by zealous early-modern Christian preachers as still being beholden to pagan practices. Reading both Protestant and Jesuit denunciations of bad habits and superstitious practices, one gains the impression that 16th-century Lithuania was still replete with paganism. On the other hand, some reports from the same period, and quite a lot of evidence of pious practices, suggest quite the opposite picture, namely that the religious situation in Lithuania was not essentially

${ }^{1}$ This topic has naturally been a favourite subject among Polish and Lithuanian historians (e.g. K. Chodynicki, 'Próby zaprowadzenia chrześcijaństwa na Litwie przed r. 1386', Przegląd historyczny, 18 (1914), pp. 215-319; J. Fijałek, 'Uchrześcijanienie Litwy przez Polskę i zachowanie w niej języka ludu', Polska i Litwa w dziejowym stosunku (Warsaw etc., 1914), pp. 39-333; S. Hain, 'Chrystianizacja Żmudzi', Annales Missiologicae = Roczniki Misjologiczne, vol. 5 (1932-1933), pp. 103-130; M. Andziulytė-Ruginienè, Žemaičiu christianizacijos pradžia (Kaunas, 1937); J. Ochmański, Biskupstwo wileńskie w średniowieczu: ustrój i uposażenie (Poznań, 1972); Chrystianizacja Litwy, ed. J. Kłoczowski (Cracow, 1987); Chrzest Litwy: Geneza, przebieg, konsekwencje, ed. M.T. Zahajkiewicz (Lublin, 1990); G. Błaszczyk, Diecezja żmudzka od XV do początku XVII wieku. Uposażenie (Poznań, 1992); G. Błaszczyk, Diecezja żmudzka od XV do poczatku XVII wieku. Ustrój (Poznań, 1993); Krikščionybès Lietuvoje istorija, ed. V. Ališauskas (Vilnius, 2006); Polish edition Dzieje chreścijaństwa na Litwie: Praca zbiorowa, ed. V. Ališauskas, translated by K. Korzeniewska (Warsaw, 2014). To date the most comprehensive work on this topic in English is represented by: M. Giedroyć, 'The arrival of Christianity in Lithuania: early contacts (thirteenth century)', Oxford Slavonic Papers, 18 n. s. (1985), pp. 1-30; idem, 'The arrival of Christianity in Lithuania: between Rome and Byzantium (1281-1341)', Oxford Slavonic Papers, 20 n. s. (1987), pp. 1-33; idem, 'The arrival of Christianity in Lithuania: baptism and survival (1341-1387)', ibidem, 1989, vol. 22, pp. 34-57. See also La Cristianizzazione della Lituania. Atti del Colloquio internazionale di storia ecclesiastica in occasione del 6 centenario della Lituania cristiana (1387-1987). Roma, 24-26 giugno 1987, ed. P. Rabikauskas (The Vatican City, 1989); Lietuvos krikščionejjimas Vidurio Europos kontekste = Die Christianisierung Litauens im mitteleuropäischen Kontext, ed. V. Dolinskas (Vilnius, 2005). For my own presentation of this topic in a nutshell, see D. Baronas, L. Jovaiša, M. Paknys, E. Raila, A. Streikus, Christianity in Lithuania (Vilnius, 2002), pp. 11-49.

2 Cf. R. Fletcher, The Conversion of Europe: from Paganism to Christianity (London, 1998 repr.), pp. 502-503. 
different from that of contemporary East and Central Europe. ${ }^{3}$ By now, it is common knowledge among historians that every epoch tends to redraft anew what is deemed to be good Christian behaviour, and that what at some time was considered acceptable could become no longer acceptable some time later, and vice versa. So it must be clear that the conversion of a country does not end paganism outright, at all levels, and in all possible respects. Conversion introduces something unequivocally new in terms of Christian church organisation and a new world-view that can be grasped most readily among elite members of a society. This relatively new thing coexists and tends to affect what are from then considered as rude habits and barbarous behaviour, or simply superstition. Changes of this sort may be regarded as a long drawn-out process of Christianisation, which, in my view, usually begins well in advance of an official conversion, and extends practically to the present. In this respect, Lithuania, too, offers an instructive example of how a pagan country assumes ever more Christian elements, which gradually combined and won the day at the end of the 14th century.

It is a long-standing tradition to try to make sense of the socalled belated conversion of Lithuania by laying the blame, as it were, on the Teutonic Order, whose military aggression against the Baltic and Finno-Ugrian tribes in the 13th and against Lithuania in the 14th centuries has been regarded as the main stumbling block on the almost natural gravitation of pagan Lithuanians towards Christianity: it is assumed that the brutal aggression of the Teutonic Order effectively discouraged pagan Lithuanians from embracing the Roman Catholic faith, and thus contributed to their strong

${ }^{3}$ Perhaps the best way to confront the evidence and the relevant judgments is to consult Baltu religijos ir mitologijos šaltiniai $=$ Sources of Baltic religion and mythology $=$ Quellen der baltischen Religion und Mythologie, ed. N. Vèlius, vol. 2: XVI amžius (Vilnius, 2001); this publication contains excerpts from sources in original languages with parallel translations into Lithuanian, and it may be easier to access than Źródła do mytologii litewskiej, ed. A. Mierzyński, vol. 1-2 (Warsaw, 1892-1896). For a general overview, see S.C. Rowell, 'Was Fifteenth-Century Lithuanian Catholicism as Lukewarm as Sixteenth-Century and Later Commentators Would Have Us Believe?', Central Europe, vol. 8, no. 2 (2010), pp. 86-106. The source of paramount importance that vividly conveys the daily routine of provincial life in 16th-century Žemaitija is a visitation of parishes conducted by Tarquinius Peculus in 1579 (see Žemaičiu vyskupijos vizitacija (1579) = Visitatio dioecesis Samogitiae (A.D. 1579), ed. by L. Jovaiša and J. Tumelis (Vilnius, 1998). 
reavowal of their native traditions. ${ }^{4}$ This tradition can be traced back as early as the first quarter of the 14th century, when Grand Duke Gediminas of Lithuania decried the Teutonic Knights as the main culprits impeding him on his road to becoming an obedient subject of the Pope. ${ }^{5}$ Much the same argumentation was picked up by Polish scholars in the early 15th century, when a Polish-German dispute over who was better at converting the pagans was in full swing. The Polish scholars' verbal attack on the Teutonic Knights was meant to drive it home that all the blame lay at the Teutonic Order's door: it was they who attacked peace-loving pagans, took away their land, maltreated them, and thus discouraged others from conversion. ${ }^{6}$ Only peaceful measures such as those deployed by the Poles at the conversion of Lithuania in 1386-1387 were truly Christian and legitimate. Half a millennium later, much the same argumentation found its way into the textbooks of history. ${ }^{7}$ For the purposes of the present paper, suffice it to say that the Teutonic Order was far from being a sinister presence in the Baltic Sea region, and pagan Lithuanians were far from peace-loving noble savages. ${ }^{8}$

Another train of argument can be characterised, broadly, as reasons of state. In the light of such supposed reasons, the Lithuanian grand dukes appear to have been very sensitive to the case of conversion precisely because of the perceived threat to the independence of

${ }^{4}$ Lietuvos istorija, ed. A. Šapoka (Kaunas, 1936, n. e. 1989), p. 110; V.T. Pashuto, Obrazovanie litovskogo gosudarstva (Moscow, 1959), pp. 363-364; J. Jakštas, 'Pavėluotas Lietuvos krikštas', LKMA Suvažiavimo darbai, 6 (1969), pp. 179, 182-187; J. Jurginis, Lietuvos krikštas: Feodalinès visuomenès socialinès ir kultūrinès raidos studija (Vilnius, 1987), pp. 74-89; R. Bartlett, The Making of Europe: Conquest, Colonization and Cultural Change, 950-1350 (London, 1993), p. 312.

5 Chartularium Lithuaniae res gestas magni ducis Gedeminne illustrans = Gedimino laiškai, ed. S.C. Rowell (Vilnius, 2003), no. 14, p. 38 (Gediminas' letter of 1322 to Pope John XXII).

${ }^{6}$ Lites ac res gestae inter Polonos Ordinemque Cruciferorum, ed. I. Zakrzewski, vol. 2 (Poznań, 1892), p. 295. For Polish-German polemics in general see T. Gruber, Die Polemik zwischen dem Deutschen Orden und Polen-Litauen (1386-1422): Stationen-Argumente-Folge (München, 2010), pp. 38-41; W. Świeboda, Innowiercy w opiniach prawnych uczonych polskich $w$ XV wieku: Poganie, żydzi, muzulmanie (Cracow, 2013), pp. 113-123 ff.

${ }^{7}$ Cf. Fijałek, 'Uchrześcijanienie', pp. 86-87.

${ }^{8}$ Cf. Rowell, Lithuania Ascending, p. xi-xiii ff. D. Baronas, 'Die Hintergründe für Litauens späte Annahme des Christentums', Annaberger Annalen über Litauen und Deutsch-Litauischen Beziehungen, 14 (2006), pp. 6-9 (6-13). 
their state. ${ }^{9}$ The rulers of pagan Lithuania are assumed to have been brought to the negotiations over the conversion of their country in reaction to the dangers emanating from foreign Christian countries, while the very intersection of these rival interests must have contributed significantly to their remaining pagan. ${ }^{10}$ Much the same reasons of state used, as it were, to discourage them from considering conversion to the Greek Orthodox rite, because this option would have given them no protection from the Teutonic Knights, who were equally eager to fight pagan Lithuanians and Russian schismatics alike. ${ }^{11}$ This picture, presented in general terms, presupposes that the pagan Lithuanians were very modern-minded, and presumably should have had a kind of think tank at the grand ducal court, which used to work out the guidelines for political action. In what follows, I will try to show that Lithuanian politics at the time defies straightforward explanations, and that there were many more forces at play than considerations of the reason of state might suggest. By doing this, I propose to focus more on individual men, and on the actual circumstances in which they had to act and react.

\section{Christians in pagan Lithuania}

Until the 13th century, Lithuania did not have towns; it lay aside from the main trade routes; its economy was largely agricultural; and its productivity only marginally exceeded subsistence level. It had about 300,000 inhabitants, at the most. ${ }^{12}$ It was not only a difficult country to access, it was also difficult to conquer, and even more difficult to establish foreign rule. It remained outside the realm of Kievan Rus', and Poland did not have easy access to it, thanks to the Iatvingians who separated the Lithuanians from the lands of the Piasts. Lithuanians began to appear regularly in historical records from the late 12th century onwards, and they did

${ }^{9}$ W. Abraham, 'Polska a chrzest Litwy', Polska i Litwa w dziejowym stosunku, p. 9. Cf. also J. Stakauskas, Lietuva ir Vakarų Europa XIII amžiuje (Kaunas, 1934, n. e. Vilnius, 2004), pp. 20, 73.

${ }^{10}$ Chodynicki, 'Próby', p. 215 ff.

${ }^{11}$ J. Ochmański, Historia Litwy (Wrocław, etc., 1967), p. 61; Z. Ivinskis, Lietuvos istorija. Iki Vytauto Didžiojo mirties (Rome, 1978, n. e. Vilnius, 1991), p. 281.

${ }^{12}$ For social-economic characteristics of Lithuania, see the respective chapters in Lietuvos istorija, vol. 3: D. Baronas, A. Dubonis, R. Petrauskas, XIII a. - 1385 m.: Valstybès iškilimas tarp Rytu ir Vakaru (Vilnius, 2011). 
this mainly in the capacity of raiders. ${ }^{13}$ Raids offered easy pickings for a robust warrior elite, who from the 1240s became accustomed to living and acting under the rule of the grand duke. This was the time when, we might say, the state of Lithuania came into being. ${ }^{14}$ I have to note only in passing that its first ruler was Mindaugas, who accepted the Roman Catholic faith in 1251, and received a royal crown from Pope Innocent IV two years later. ${ }^{15}$ This Christian and royal interlude in Lithuania's history lasted only a decade, and after the king was assassinated in 1263, the country relapsed into political turmoil, out of which it emerged united under the sole rule of an energetic pagan duke named Traidenis. ${ }^{16}$ From then, and up to the times of Jogaila, more widely known in Polish as Władysław II Jagiełło, Lithuania was ruled continuously by pagan rulers. The territorial backbone of the state, with grand ducal castles, manors, and the first towns, began to form after the times of Traidenis. However, the most decisive steps seem to have been taken by his (unrelated in terms of kinship) successors, whose progeny would in time obtain the charming name of the Gediminid and Jagiellonian dynasty. It looks likely that it was Grand Duke Vytenis (1295-1316)

${ }^{13}$ A good overview of this phenomenon in a language more accessible than Lithuanian may be found in H. Paszkiewicz, Jagiellonowie a Moskwa, vol. 1: Litwa a Moskwa w XIII i XIV wieku (Warsaw, 1933), p. 25 ff.

14 Still the best monograph on the process of state formation in Lithuania is H. Łowmiański, Studja nad początkami społeczeństwa i państwa litewskiego, vol. 1-2 (Vilnius, 1931-1932). For the time of Mindaugas, see also E. Gudavičius, Mindaugas (Vilnius, 1998).

15 Z. Ivinskis, 'Mindaugas und seine Krone', Zeitschrift für Ostforschung, vol. 3, no. 3 (1954), pp. 360-386; M. Hellmann, 'Der Deutsche Orden und die Königskronung des Mindaugas', ibidem, pp. 387-396.

16 There is a long-term scholarly debate concerning the presumed apostasy of King Mindaugas in c. 1261. Cf. J. Stakauskas, Lietuva ir Vakaru Europa XIII a. (Vilnius, 2004, first edition 1934), pp. 185-240; D. Baronas, 'Karalius krikščionis Mindaugas popiežių akimis', Mindaugas Karalius, ed. V. Ališauskas (Vilnius, 2008), p. 28; idem, 'Katholisches und orthodoxes Litauen', Lietuvos valstybès susikūrimas europiniame kontekste, ed. R. Petrauskas (Vilnius, 2008), pp. 269-273. This matter is far from being so unequivocal as one might suppose from general works available in English that favour the theory of Mindaugas' apostasy from Christianity and his return to paganism. See e.g. Fletcher, Conversion of Europe, pp. 505-506; Christianization and the rise of Christian monarchy: Scandinavia, Central Europe and Rus'c. 900-1200, ed. by N. Berend (Cambridge, 2007), p. 35. The definitive study on Grand Duke Traidenis is that by A. Dubonis, Traidenis: Monarcho valdžios atkūrimas Lietuvoje (1268-1282) (Vilnius, 2009). 
who chose Vilnius as the site for his main residence. ${ }^{17}$ It is true that credit for the foundation of Vilnius went to his brother Gediminas, who made Vilnius the permanent capital city of Lithuania: he seems simply to have elaborated on the foundation laid down by Vytenis, and to have been more blessed with a numerous family and better historical records. ${ }^{18}$ But as far as Vytenis is concerned, we should state a kind of paradox: from historical records, he looks like a hardened, bragging warrior, who enjoyed taking part in battles, and leading bands of raiders to collect booty and slaves. ${ }^{19}$ Yet from archaeological evidence, he comes across as the builder of the first large wooden castle on Gediminas Hill in Vilnius, and the one who settled the first foreign (Christian) craftsmen, and perhaps also merchants, close to his new residence, on the site of present-day Cathedral Square. They must have been German newcomers from Livonia, mainly from Riga, a town which then had good relations with Vytenis. ${ }^{20}$ It is understandable that in medieval conditions, no Western craftsman or tradesman could dispense with the clergy or the Church for any period of time. So it is not surprising that the earliest remains of the Christian Church in Lithuania to date were discovered beneath the floor of the present cathedral in Vilnius. There is a vigorous debate as to what date to ascribe this church to: some people are very eager to advocate the idea that this place must also have served as the pagan shrine that was destroyed by Jogaila in 1387, and then rebuilt as the main Catholic church of Lithuania. ${ }^{21} \mathrm{I}$ admit there are differences of opinion, but at the same time I would like to say that not all of them are equally well founded, and that is why I am inclined to subscribe to the view

${ }^{17}$ G. Vaitkevičius, Vilniaus ịkūrimas (Vilnius, 2010), pp. 54-56.

18 Rowell, Lithuania Ascending, pp. 55-59.

${ }^{19}$ For his military raids to Polish lands, see G. Błaszczyk, Dzieje stosunków polsko-litewskich od czasów najdawniejszych do wspótczesności, vol. 1: Trudne poczatki (Poznań, 1998), pp. 52-54. For his military actions against the Teutonic Knights, see W. Urban, The Samogitian Crusade (Chicago, 1989), pp. 52-62; D. Prekop, Wojna zakonu krzyżackiego z Litwa w latach 1283-1325 (Toruń, 2004), pp. 80-130; M. Radoch, Walki Zakony Krzyżackiego o Żmudź od połowy XIII wieku do 1411 roku (Olsztyn, 2011), pp. 38-44.

${ }^{20}$ Vaitkevičius, Vilniaus ìkūrimas, pp. 60-61.

${ }^{21}$ For a critical evaluation of this theory, see D. Baronas, 'Perkūno šventykla Vilniuje: senų mitų ir naujų mokslinių tyrimų nedermè', Naujasis Židinys-Aidai, no. 7 (2012), pp. 442-447. 
that these earliest remains represent the remains of a Franciscan church. ${ }^{22}$ The members of this mendicant order are best attested to in 14th-century sources pertaining to Vilnius. ${ }^{23}$ So the Franciscans, together with new German settlers, constituted the main segment of the Catholic population in pagan Vilnius. They enjoyed the protection of the grand duke, and were allowed to rule themselves according to their customary laws. There were also some Catholic Poles in Lithuania, whose social status seems to have been inferior, mainly because most of them tended to be captives resettled in Lithuania as slaves. The Polish presence in Vilnius is off the map until the end of the 14th century. In pagan Lithuania, Poles used to live dispersed in the manors of the Lithuanian nobility. ${ }^{24}$

Orthodox East Slavs, also known as Ruthenians, constituted yet another segment of the Christian population in pagan Lithuania. Most

22 Vaitkevičius, Vilniaus ịkūrimas, pp. 21, 60-61.

${ }^{23}$ See e.g. D. Baronas, Vilniaus pranciškonu kankiniai ir ju kultas XIV-XX a. (Istorine studija ir šaltiniai) = Fratres Minores Martyres Vilnenses Eorumque Cultus Saec. XIV-XX (studium historicum et editio fontium) [Studia franciscana lithuanica, vol. 4] (Vilnius, 2010), pp. 77-98.

${ }^{24}$ Lietuvos istorija, vol. 3, pp. 293-295. Polish scholars used to exaggerate the influence of the Polish captives in spreading the Christian faith in pagan Lithuania. They imagined Polish captives to have been living in closely knit village communities and ministered by (captive) Catholic clergy. Cf. e.g. Abraham, 'Polska a chrzest Litwy', p. 12; A. Wróblewski, 'Chrystianizacja Litwy górnej', Novum, 7-8 (1971), p. 88. In our view, such an image is much more indebted to the situation of the Vilnius region (Wileńszczyzna) in the 19th and 20th centuries than it is a reflection of medieval realities. Of course, some captive women (Polish Catholic and Ruthenian Orthodox alike) had their share in acquainting at least some pagan Lithuanians with their Christian religion, as may be inferred from a reference in a 13th-century tract Descriptiones terrarum to wetnurses. This influence could be only very circumscribed, and its perception was formed not only by the experience in the Lithuanian 'missionary field', but also by the bright hopes current among mendicant friars in the time of the Christian rule of King Mindaugas. See M.L. Colker, 'America rediscovered in the thirteenth century?', Speculum, 54 (1979), p. 723. On the possible author of this tract, see K. Górski, 'Descriptiones terrarum (Nowo odkryte źródło do dziejów Prus w XIII wieku)', Zapiski Historyczne, vol. 46, no. 1 (1981), pp. 7-16; J. Ochmański, 'Nieznany autor 'Opisu krajów' z drugiej połowy XIII wieku i jego wiadomości o Bałtach', LituanoSlavica Posnaniensia, 1 (1985), pp. 107-114; K. Stopka, 'Misja wewnętrzna na Litwie w czasach Mendoga a zagadnienie autorstwa 'Descriptiones terrarum', Nasza Przeszłość, 68 (1987), pp. 256, 258; G. Freibergs, 'The Descripciones Terrarum: its date, sources, author and purpose', Christianity in East-Central Europe, ed. by J. Kłoczowski, vol. 2 (Lublin, 1999), pp. 180-201. 
of them should have been concentrated in Kernavè (the 'capital' of Traidenis), and in Vilnius. ${ }^{25}$ Their settlement in Vilnius was some distance from the grand-ducal castle, and it was known as 'civitas Ruthenica'. ${ }^{26}$ According to the most recent results obtained by the archaeologist Rytis Jonaitis, the first newcomers may have settled there in the last quarter of the 13th century, presumably still in the times of Traidenis. ${ }^{27}$ Although Orthodox settlement may predate that by Roman Catholics, knowing that Carbon-14 dating without the evidence of written sources is highly debatable, we may quite safely say that both these communities settled at much the same time, almost contemporaneously. This must have been the result of the conscious policy of the grand dukes to avail themselves of the skilled workforce necessary to maintain their court at the required level of sophistication, and to support their military efforts in faraway lands with the necessary level of efficiency. This combination of pagan militancy and Christian craftsmanship and mercantilism was a solution that worked to some degree, and at least for some time.

${ }^{25}$ As regards Kernavè, the most interesting archaeological site for our purposes is the nearby Kriveikiškès burial ground. It displays inhumations, and stands in contrast to the then pravailing custom of cremation. Some archaeologists assume that the Kriveikiškès burial ground serves as an indication of the presence of a Christian Orthodox population in Kernavè: G. Zabiela, 'Laidosena pagoniškoje Lietuvoje', Lietuvos archeologija, 15 (1998), pp. 356-358. Other archaeologists emphasise the similarity of grave goods found at Kriveikiškès to those that are characteristic of Iatvingian tribes. G. Vèlius, Kernaves miesto bendruomene XIII-XIV amžiuje (Vilnius, 2005), pp. 53, 88. On balance, it seems most plausible to suggest that the population of Kernave was a mixed one. Its lower strata (artisans, traders, servitors) were made up of subject pagan and Ruthenian (Orthodox Christian) populations, while the luxury finds on the site of the wooden castle on Aukuras hill serves as an indication of the pagan ruling elite (the grand duke and his men). Ibid., p. 88 . Dubonis, Traidenis, pp. 167-168.

${ }^{26}$ This name of the Ruthenian quarter of Vilnius is attested to by Wigand of Marburg in his description of the 1384 siege of Vilnius by the troops of the Teutonic Order (see 'Die Chronik Wigands von Marburg', Scriptores rerum prussicarum, vol. 2 (Leipzig, 1863, p. 623). In modern Lithuanian historiography, the term 'civitas Ruthenica' acquired a new life and became applicable to designate that part of Vilnius Old Town which from the late 13th century was inhabited by East Slav (and/or Orthodox) townspeople. See also D. Baronas, 'Drevneyshiye sledy prebyvaniya russkikh v Vil'nyuse', Slavistica Vilnensis (= Kalbotyra), vol. 53 (2) (2004), pp. 161-166.

${ }^{27}$ News based on an oral presentation by Rytis Jonaitis in a seminar held at the Lithuanian Institute of History on 23 May 2013. 
The need of the grand dukes to have skilled manpower at their disposal was displayed most eloquently in the letters of Gediminas, whereby he invited Roman Catholic peasants, artisans, merchants and knights to come and settle in Lithuania. He promised them freedom to practise their faith, he guaranteed them the most welcome conditions for living, and assured them that after the payment of a tithe (to be paid after ten years of residence), their net gains would still be much higher than those in their native countries. ${ }^{28}$ Although no mass influx of happy newcomers can be proven, the letters of Gediminas show him as a pragmatic ruler, of a sort who was keen on getting from the West what was most necessary for his power, without committing himself too eagerly to the spiritual values that made those valuable things possible.

Contacts between Christians and pagans were not limited to the battlefield. Peaceful contacts were always possible, and in some instances they certainly contributed to individual conversions. As might be expected, the first local Lithuanian Christians should be looked for among traders. The Riga debt-book enumerates a number of Lithuanian merchants bearing Christian names. ${ }^{29}$ In all probability, they must have received baptism in the Latin rite. From the mid-13th century, it was not unusual for Lithuanian princes and their subjects to receive baptism in the Orthodox rite upon their coming to rule Ruthenian principalities annexed by Lithuania. ${ }^{30}$ Some members of the house of Alšeniškiai adopted the Orthodox faith before the final introduction of the Catholic faith to Lithuania in 1387. Despite their Orthodoxy, they even managed to retain their prominent position

${ }^{28}$ Chartularium, p. 60 (Gediminas' letter of 26 May 1323, to the city fathers of Lübeck, Rostock, Stralsund, Greifswald, Szcecin and other Hanseatic merchants and craftsmen).

29 Das Rigische Schuldbuch (1286-1352), ed. H. Hildebrand (St Petersburg, 1872), p. 19, no. 251: Johannes Maseghe; p. 36, no. 483; p. 49, no. 707; p. 108, no. 1715: Johanes Bitovte; p. 82, no. 1255: Petrus Letowinus.

${ }^{30}$ One of the first and most famous cases in point is provided by the son of King Mindaugas of Lithuania, Vaišvilkas (Vaišelga, Vojshelk), who became an Orthodox believer after spending some time in Belarusian Novahrudok in c. 1254, and ruled in Lithuania in 1264-1267. See e.g. D.M. Goldfrank, 'The Lithuanian Prince-Monk Vojšelk: a study of competeing legends', Harvard Ukrainian Studies, vol. 11, no. 1-2 (1987), pp. 44-76. An overview with an emphasis on the 15th-16th centuries is provided by M. Liedke, 'Następstwa chrystianizacji Giedyminowiczów przed 1386 r.', History, Culture and Language of Lithuania. Proceedings of the International Conference, Poznań 17-19 September 1998, ed. G. Błaszczyk, M. Hasiuk (Poznań, 2000), pp. 117-127. 
among the ruling elite. ${ }^{31}$ The very circumstances of Lithuania's conversion in 1387 reveal a religious situation which was far more complicated than it could be supposed from an abstract image of the pagan country. By this time, not all Lithuanians were pagan, and some followed different rites in such sufficient numbers as to make it enough to work out precautionary measures against the dissemination of Orthodoxy among the Lithuanians in $1387 .{ }^{32}$ All in all, these remarks show that the decline of the pagan religion was well advanced before the final conversion to Christianity.

\section{On the road to change}

The question of Lithuania's conversion to Roman Catholicism was repeatedly raised throughout the 14th century, be it in sporadic contacts with the papacy, or in dealings with prominent rulers of East and Central Europe such as Casimir III the Great of Poland, Louis I the Great of Hungary or Charles IV of Bohemia. All these attempts at conversion failed. ${ }^{33}$ Historians coming to grips with these issues tend to point to geo-political and socio-political considerations. They also tend to represent the ruling elite of Lithuania as a one-headed body imbued with an identical set of political and religious priorities. I believe that in doing so we miss some significant points. Pagan Lithuania was far from being a centralised country, its turbulent foreign and domestic policies show that it was a difficult country to rule, maintain and expand. After the demise of almost every grand duke, it had to be virtually reconstituted anew. Taking into account these phenomena, I would like to use what I would call a group-oriented approach. By this, I mean that there were different groups of dukes and princes, with their different entourages, even within the same ruling family. I have a suspicion that they had essentially stable, though by no means identical, sets

${ }^{31}$ Die Chronik Wigands von Marburg, p. 604; S.C. Rowell, 'Gediminaičių dinastinè politika Žemaitijoje 1350-1430’, Žemaičiu praeitis, vol. 3, 1994, pp. 131-133.

32 Cf. Akta unii Polski z Litwa, ed. S. Kutrzeba, W. Semkowicz (Cracow, 1932), p. 2; Codex diplomaticus ecclesiae cathedralis necnon dioceseos Vilnensis $=$ Kodeks dyplomatyczny katedry i diecezji wileńskiej $(K D K D W)$, ed. J. Fijałek, W. Semkowicz, vol. 1 (Cracoviae, 1932-1948), p. 13. 'Sofiyskaya pervaya letopis' starshego izvoda', Polnoye sobraniye russkikh letopisey (hereafter - PSRL), vol. 6 (Moscow, 2000), col. 489-490.

33 Christianity in Lithuania, pp. 38-45. 
of priorities. We must also bear in mind that Lithuanian society was an essentially patriarchal one, in which men of advanced age enjoyed the most authority. The dukes usually ascended the throne as mature men with years of harsh experience behind them, and in no rush to change their views.

So I suppose that dukes such as Traidenis, Vytenis, Gediminas, Algirdas and Kęstutis might all be ascribed to a group that could loosely be called 'a conservatively pagan party'. All of them were served up an option to convert to the Roman Catholic faith. None of them treated it seriously, as some sort of political goal to be achieved by premeditated policy-making. Some of them, like Gediminas and Algirdas, were instrumental in making a number of rash Franciscan friars $(1341,1369)$ and recalcitrant Orthodox courtiers (1347) martyrs for the faith. ${ }^{34}$ Presumably, all of these dukes emphasised the martial (and, by implication, victorious) qualities of their pagan gods. ${ }^{35}$ On one occasion, Vytenis reportedly trampled on the Host in front of

34 On these martyrdoms in 14th-century Lithuania, see my two monographs where relevant source material and pertinent bibliographical lists are supplied: D. Baronas, Trys Vilniaus kankiniai: istorija ir gyvenimas (istoriné studija ir šaltiniai) = Tres martyres Vilnenses: Vita et historia (studium historicum et editio fontium) (Vilnius, 2000) and idem, Vilniaus pranciškonu kankiniai ir ju kultas XIV-XX a. (istorine studija ir šaltiniai) = Fratres Minores Martyres Vilnenses Eorumque Cultus Saec. XIV-XX (studium historicum et editio fontium) (Vilnius, 2010). The 1347 martyrdom of the Orthodox saints Anthony, John and Eustachius and its documentary evidence are discussed by idem, 'The Three martyrs of Vilnius: a fourteenth-century martyrdom and its documentary sources', Analecta Bollandiana, vol. 122, no. 1 (2004), pp. 83-134.

35 S.C. Rowell, Lithuania Ascending, p. 146. At the same time, it must be noted that despite pagan Lithuania's culture having been strongly militaristic in nature, the ideological trappings of what is called 'triumphal rulership' seem to have been weakly developed if compared to early medieval Barbarian kingdoms. Pagan Lithuanians did celebrate military victories, as might be seen from an aside made by Peter of Dusburg, that up to his days the Žemaitians were proud of their victory over the Teutonic Knights at the Battle of Durbė (1260). Petri de Dusburg Chronicon terrae Prussiae, vol. 1 (Leipzig, 1861), p. 97. They also burnt some captive Teutonic Knights as offerings to their gods. However, the more elaborate rituals of celebrating military exploits are conspicuously lacking. In our view, this may at least partly be explained by reference to cultural milieu: in contrast to early medieval Barbarian kingdoms, pagan Lithuania was lacking a Roman imperial cultural substratum which was permeated with the ideology of victory. On this see M. McCormick, Eternal victory. Triumphal rulership in late antiquity, Byzantium, and the early medieval West (Cambridge, 1986), p. $260 \mathrm{ff}$. 
his Christian captives, to show them that their God was weak, and his gods were strong. Different accounts of this blasphemous act betray the tendency on the part of chroniclers serving the Teutonic Order to immerse their readers and hearers ever more deeply in an eerie world of paganism. Peter of Duisburg, writing relatively close to an event he describes (1311 and the 1320s), reports that Vytenis led his army to devastate the Diocese of Warmia, and in so doing showed, among other things, disrespect for the clergy and liturgical apparel; after that, blaspheming the name of Jesus Christ, he braggingly asked his Christian captives where their God was. ${ }^{36}$ At the end of the century, the same scene was reproduced in more gruesome detail by Wigand of Marburg, who depicted Vytenis as trampling on the Host, and quoted his alleged words. ${ }^{37}$ It was a staple accusation of the infidels in general, at a time and in the milieu in which Wigand of Marburg composed his rhymes. ${ }^{38}$ Despite fine details, any performance of this kind must certainly have had a bearing on real onlookers or a Christian audience, so both these chroniclers did not fail to tell their audience that in the end a sharp defeat inflicted on the Lithuanian army by the Teutonic Knights made their God's answer to Vytenis' question reassuringly clear.

We may also note that such descriptions are rather rare, and in general such behaviour on the part of Lithuanian dukes must have been exceptional; but the message 'let's see how strong our gods are' could well be quite a common one, expressed in not-soextravagant ways. Half a century later, when prince Kęstutis was in desperate need of military success, ${ }^{39}$ he and his brother Algirdas and some other relatives launched a raid against the Teutonic Order. The raid was quite successful, and, in thanksgiving to their gods, the pagans sacrificed a wild ox and burned a certain Ger-

${ }^{36}$ Petri de Dusburg Chronicon terrae Prussiae, p. 176.

${ }^{37}$ Die Chronik Wigands von Marburg, p. 456.

38 Codex epistolaris Vitoldi magni ducis Lithuaniae, 1376-1430 (CEV), ed. A. Prochaska (Monumenta medii aevi historica res gestas Poloniae illustrantia, vol. 6) (Cracow, 1882), no. 597, p. 295 (25 September 1414).

${ }^{39}$ For this period in the life of Kęstutis, see D. Baronas, 'Die Flucht des litauischen Fürsten Kęstutis (Kynstut) aus der Marienburg 1361 und die Frage, ob der Deutsche Orden an seiner Gefangenschaft interessiert war', Annaberger Annalen über Litauen und Deutsch-Litauischen Beziehungen, 12 (2004), pp. 9-27. 
man alive. The show must have been quite impressive, as some 800 local people surrendered to the pagans, and were subsequently resettled in Eastern Lithuania, where their presence was known in the last decade of the 14 th century. ${ }^{40}$ It looks likely that Kęstutis was able for some time to reinforce his authority. But in the long run, it proved increasingly difficult for pagan leaders to show off with huge territorial gains and splendid victories. The second half of the 14th century began to show cracks in the united effort of pagan militancy and Christian craftsmanship. This was one of the reasons why other parties could enter the political scene. Besides the pagan party, we can talk of the Orthodox party, made up mostly of Algirdas' Orthodox sons. Another group can be seen in the sons of Prince Karijotas (the son of Gediminas), who from the second half of the 14th century established their rule in present-day Podolia. They displayed pro-Catholic, pro-Western inclinations, and some of them acknowledged the suzerainty of either the Polish or Hungarian king. ${ }^{41}$ The most influential party was the one which coalesced around Jogaila and Skirgaila, both sons of Algirdas and his second wife Iuliana of Tver'. After the death of their father in 1377, they were still pagans, but their paganism was no longer an obstacle to them to go ahead and finally bring themselves and most of their pagan Lithuanian subjects to the Roman Catholic fold. With the violent death of the septuagenarian duke Kęstutis in 1382, the pagan party lost its last significant representative. His most able son Vytautas overtook Jogaila by becoming a Catholic in $1383 .{ }^{42}$ In a short space of time, when the internal strife subsided and Jogaila had already married the Polish Queen Jadwiga of Anjou, and himself become King of Poland (1386), the mass conversion of pagans

40 'Die Chronik Wigands von Marburg', p. 549, footnote no. 748.

${ }^{41}$ The issue of the Karijotaičiai (Kariotovichi) clan coming to rule in Podolia has received much attention from generations of scholars. Due to the lack of coverage in contemporary sources, and the highly partisan nature of later sources, many issues remain unclear and under discussion. The current state of knowledge on this topic with well-informed judgements has been presented by J. Kurtyka, 'Podole pomiędzy Polską i Litwą w XIV i 1. połowie XV wieku', Kamieniec Podolski. Studia z dziejów miasta i regionu, ed. by F. Kiryk, vol. 1 (2000), pp. 13-18.

42 On Vytautas as the Grand Duke of Lithuania, see the latest monograph by J. Nikodem, Witold wielki ksiązę litewski (1354 lub 1355 - 27 października 1430) (Cracow, 2013), pp. 82-83 (his baptism). 
became imminent. Jogaila was intent on making all Lithuanian pagans embrace the Roman Catholic faith. ${ }^{43}$ Now the boot was on the other foot. It looks likely that some objects of the pagan cult were destroyed, in recognition of the new order of things to come, but the description of the demolition of the pagan temple in Vilnius by Jan Długosz seems to be much exaggerated. ${ }^{44}$ Anyway, there was no violent pagan opposition or reaction to the introduction of the new Christian religion. An attempt was also made to insulate the Lithuanian population from Russian Orthodox influences. Lithuanians who were already Orthodox were, as a rule, exempt from the requirement to accept Roman Catholicism. It is true that Russian chronicles mention two Orthodox Lithuanians who were executed for their refusal to switch to the Catholic side, but this event, if true, defies a straightforward explanation, for lack of any other evidence on this exceptional piece of information. ${ }^{45}$ The death penalty for refusing to be (re)baptised in the Latin rite would have flown in the face of even the harshest ecclesiastical censures, so that is why this unique and isolated piece of information, standing in sharp contrast to the attested presence of Lithuanian Orthodox believers in postconversion Lithuania, seems to be a product of over-interpretation by Muscovite chroniclers, with regard to some event whose actual circumstances are not known.

\section{Vilnius in 1387: the silent passing of paganism}

Vilnius occupies the most important place in the history of Lithuania. It was the 'royal town' from its first record in the 1323 letter of Grand Duke Gediminas. ${ }^{46}$ Since then, it may justly be regarded as the nerve centre of the Grand Duchy of Lithuania. It was certainly

43 This promise was already given in 1385 , when Lithuanian-Polish negotiations were under way in the castle of Kreva. The recent edition of the Act of Krèva, 14 August 1385, is contained in $1385 \mathrm{~m}$. rugpjūčio $14 \mathrm{~d}$. Krèvos aktas, ed. J. Kiaupienè (Vilnius, 2002), pp. 17-20.

${ }^{44}$ Ioannis Dlugosii Annales, liber XI, p. 159. This issue is dealt with more exhaustively in a book written by D. Baronas and S.C. Rowell, The Conversion of Lithuania: From Pagan Barbarians to Late Medieval Christians (Vilnius, 2015). For some of the topoi that may be related to the interpretatio Romana of the pagan religion in Lithuania, see D. Baronas, 'Žemaičių krikštas Jono Dlugošo kronikos šviesoje', Istorijos šaltiniu tyrimai, 3 (2011), pp. 23-30.

${ }^{45}$ Novgorodskaya karamzinskaya letopis', PSRL, vol. 42 (St Petersburg, 2002), p. 150 .

${ }^{46}$ Chartularium, p. 62. 
not an accident that it was precisely in Vilnius that the martyrdom of Franciscans in around 1341 and 1369 took place. ${ }^{47}$ The same holds true of the three Orthodox martyrs of Vilnius in circa 1347: although the extant sources do not indicate expressis verbis the site of their martyrdom, due to circumstantial evidence and the subsequently developed tradition, this choice is the most plausible one. ${ }^{48}$ The miracles surrounding the 1341 martyrdom of the Franciscans indicate that a number of pagans converted as a result. ${ }^{49}$ The activities of Cyprian (a future metropolitan of Kiev and All Rus') in Vilnius in 1374 were closely related to the incipient cult of the Three Martyrs of Vilnius, and also, as a result, a number of pagans converted to the Orthodox faith. ${ }^{50}$ It is impossible to tell how, if at all, such converts could maintain their newly acquired faith, but thanks to the existence of the Christian houses of prayer, this seems to be more than possible.

It is assumed that the earliest churches in Vilnius were built some time before 1323, when Gediminas wrote in his letters that he recently had two churches constructed in Vilnius, one for the Friars Minor, the other for the Dominicans. To our knowledge, virtually all authors dealing with this evidence (including myself) believe in the veracity of this piece of information. ${ }^{51}$ However, on a closer analysis of the letters of Gediminas, some problems arise. It is true that there is no reason to doubt the existence of the Franciscan church, because it is mentioned in a superb document, the report of envoys of the papal legates. ${ }^{52}$ The case with the Dominican church is much more complicated. In contrast to the letter addressed to the Franciscans of Saxony, in which there is a mention of a church built for their

${ }^{47}$ On the Franciscan martyrs, see S.C. Rowell, 'Lithuania and the West, 1337-41. A Question of Sources', Journal of Baltic Studies, vol. 20, no. 4 (1989), pp. 303-326. D. Baronas, Vilniaus pranciškonu kankiniai.

48 On the Vilnius Orthodox martyrs (Sts Anthony, John and Eustachius), see Baronas, Trys Vilniaus kankiniai..., and idem, 'The Three martyrs', pp. 83-134.

49 'Chronica XXIV Generalium', Analecta Franciscana, vol. 3 (Quaracchi, 1897), p. 536.

${ }^{50}$ Baronas, 'The Three Martyrs', pp. 110-111, 116-121. See also the letter of Metropolitan Cyprian to St Sergius of Radonezh (23 June 1378) published in: Russkaya istoricheskaya biblioteka, vol. 6 (St Petersburg, 1908, 2nd ed.), col. 182.

${ }^{51}$ Chartularium, p. 46 (25 January 1323). For an exception see E. Remecas, 'Vilniaus gaisro datavimo problematika: ar tikrai Vilniaus pilis sunaikino $1419 \mathrm{~m}$. gaisras?', Lietuvos pilys, vol. 6 (2010), p. 83.

52 Chartularium, p. 182 (3 November 1324). 
order, ${ }^{53}$ there is no mention of a church built for the Dominicans in the letter addressed specifically to them. ${ }^{54}$ It is mentioned, as has just been explained, in a general missive of 25 January 1323, in which there is a statement that the church in question was built two years before (infra duos annos). However, in the letter of 26 May 1323 to the Franciscans, Gediminas stated that he was only going to commit one church to friars preachers. ${ }^{55}$ This discrepancy certainly makes a difference. Add to this that there is no other contemporary evidence or later tradition about a Dominican church in Vilnius in the 14th century, it must be concluded that Grand Duke Gediminas exaggerated his 'good news' to the neighbouring Roman Catholic world in general and to the Dominicans in particular. The oldest surviving Roman Catholic church in Vilnius (and Lithuania) is that of St Nicholas. It was built in an area which began to be densely inhabited from the last quarter of the 14th century onwards. It was German (Roman Catholic). It is mentioned for the first time in the 1387 charter of Jogaila, and must already have been built before the final conversion of the country. ${ }^{56}$

As regards the Orthodox churches in Vilnius, the sources are similarly meagre. It looks plausible that the Orthodox church of St Nicholas could have been standing, because that was the place where the Three Martyrs of Vilnius were originally buried. ${ }^{57}$ Another church which was built during the rule of Algirdas is that of the Holy Trinity. Initially it was a wooden structure, erected in $1374 .{ }^{58}$

This overview shows that there were Christians in Vilnius in pagan times. So the claim by the Russian chronicler that Jogaila

53 Ibid., p. 62 (26 May 1326).

${ }^{54}$ Cf. Ibid., pp. 56-58 (26 May 1326).

${ }^{55}$ Ibid, p. 64: 'et eciam de Praedicatoribus, quibus dabimus ecclesiam tempore successivo' (26 May 1323).

${ }^{56} K D K D W$, no. 1 , p. 5 (17 February 1387). The claim of a German scholar that St Nicholas' Church in Vilnius 'must have been built before 1150' is totally misleading. K. Blaschke, U. Jäschke, Nikolaikirchen und Stadtenstehung in Europa: Von der Kaufmannssiedlung zur Stadt (Berlin, 2013), p. 85. Still to commend is P. Reklaitis, 'Die St. Nicolaikirche in Wilna und ihre stadtgeschichtliche Bedeutung', Zeitschrift für Ostforschung, vol. 8, no 4 (1959), pp. 500-522.

57 This wooden church has not survived (it finally disappeared in the great fire of Vilnius in 1610). Archaeological investigations conducted in 1981 on this site revealed that this place was one of the earliest on which Orthodox believers settled in Vilnius. See Zabiela, 'Laidosena pagoniškoje Lietuvoje', p. 358.

58 The confirmation in sources for its existence is not straightforward, but nonetheless compelling enough. See Baronas, 'The Three Martyrs', pp. 90-93. 
converted half a town to the German (Roman Catholic) faith seems rather plausible, though it ought not to be taken too literally. ${ }^{59}$ The 'half' that converted to the Roman Catholic faith was the pagan half of the population, while the other half must have already been Orthodox and Catholic.

After the final conversion of the Lithuanian pagans in 1387, the Christian way of life became part and parcel of everyday life quite quickly. The religious practices of the Catholic population had to be conducted according to the Roman Catholic calendar. That certainly constituted something new for neophytes. It must be stressed that from the very beginning, the city (civitas) of Vilnius, with its newly built cathedral, was conceived as a showcase for Roman Catholic piety, and the place where the new Christian identity of the Lithuanians was to be displayed to the best effect. When the papal envoy Giovanni Manco visited Vilnius in 1390, to make an inspection, he gained quite a positive impression regarding the Christian way of life of its inhabitants. ${ }^{60}$ Quite soon, Roman Catholic piety no longer needed to be displayed in front of high-ranking visitors in order to persuade the Roman Curia that good Catholics were living there. The 'other', in the form of the Ruthenians, however, remained and was alive and well. It was the Orthodox believer who had to be impressed; it was not only one's own spiritual demands that had to be satisfied. The need to impress, and, if possible, to convert Orthodox believers, is evident from the confirmation the Roman Catholic bishops placed (in different times in the second half of the 15 th century) on the foundation charter of the confraternity at the Church of St John in Vilnius. ${ }^{61}$ They were not to submit as quietly as pagans converting without much ado in 1387 .

\section{Pagans in early Christian Lithuania: neither fish nor fowl?}

In the first half of the 15th century, pagans could still be encountered in Žemaitija, a land which due to its disputed political affiliation remained largely beyond the rule of either the Teutonic Order or the Grand Dukes of Lithuania. After the Battle of Tannenberg, Žemaitija

59 Novgorodskaya karamzinskaya letopis', p. 150.

${ }^{60}$ J. Drabina, Papiestwo-Polska w latach 1384-1434 (Cracow, 2003), pp. 27-28.

${ }^{61}$ Berlin (Dahlem) Geheimes Staatsarchiv Preußischer Kulturbesitz. 'Urkundensammlung Zasztowt', Schieblade No. 6 (11 February 1454). 
returned to Lithuanian rule, and was converted in 1413-1417. ${ }^{62}$ These decisive years witnessed no pagan reaction in Žemaitija, and only the next year saw an uprising staged by 'bad people' against 'good people' (nobles). I intentionally use terms such as 'bad' and 'good' that reflect the parlance of historical sources, because the causes of this uprising are rather unclear. Historians in the 19th and 20th centuries saw in it the usual example of a pagan reaction to the new religion. ${ }^{63}$ In my opinion, however, more circumspection is needed here. The quite eloquent correspondence between Grand Duke Vytautas and officials of the Teutonic Order has no mention of pagan activities directed against the newly established churches and newly settled ecclesiastics in newly converted Žemaitija. ${ }^{64}$ Speaking rather figuratively, one gets the impression that Vytautas and the Teutonic Knights wrote volumes about the most simple and casual brigandage, but passed over in silence anything to do with deadly threats to priests, bishops and their churches, things that are mentioned in a rather flawed piece of information supplied only by the chronicle of Johannes von Possilge. ${ }^{65}$

It is true that Jogaila and Vytautas promoted boyars who were eager to cooperate with them, at the expense of those who were more interested in upholding the inherited status quo. ${ }^{66}$ The latter could not be happy with new developments, nor could those peasants who were granted to 'good people' to serve. So, on balance, it seems that troublemakers in Žemaitija were much more concerned with the preservation of their usual way of life than with the finer points of the old or the new religion. It is true that in the times of Vytautas, overt paganism was no longer possible. In general, the nobility in Žemaitija, as well as in eastern Lithuania, accepted the

${ }^{62}$ Fijałek, 'Uchreścijanienie Litwy’, pp. 70-118. Andziulytè-Ruginienè, Žemaičiu christianizacijos pradžia. On the political situation in Žemaitija at the end of the 14 th and the beginning of the 15 th century, see V. Almonaitis, Žemaitijos politine padetis 1380-1410 (Kaunas, 1998).

${ }^{63}$ M. Valančius, Raštai, ed. B. Vanagienè, V. Merkys, vol. 2 (Vilnius, 1972), pp. 55-57. Fijałek, 'Uchreścijanienie Litwy', p. 107; Maironio raštai, vol. 4: Lietuvos praeitis. Ketvirtoji laida, žymiai perdirbta (Kaunas, 1926), p. 125. Ivinskis, Lietuvos istorija, p. 354.

${ }^{64}$ CEV , no. 777 , pp. 408-409; no. 778, p. 408; no. 779, pp. 409-410; no. 781, pp. 411-412 (all of June 1418).

65 'Johann von Posilge Fortsetzung', SRP, vol. 3 (Leipzig, 1866), p. 376.

${ }^{66}$ On the internal life of Žemaitija, see the fundamental study of E. Saviščevas, Žemaitijos savivalda ir valdžios elitas 1409-1566 metais (Vilnius, 2010). 
new Christian religion as a matter of fact, and some, undoubtedly, as a matter of heart. What about the possibility for individual members of the noble estate to remain pagan well into the 15 th century? There is one known instance about a pagan called Daumantas. He was, aptly, from Žemaitija. Virtually all historians who come across him consider him pagan. ${ }^{67}$ Daumantas the pagan was at the head of the Žemaitjans, who, after Grand Duke Žygimantas, the son of Kęstutis, was killed in 1440, supported his son Michael in the latter's bid to become Grand Duke of Lithuania. The pagan supporting the Christian pretender. This picture, despite its appearance and long-term historiographical tradition, is far from reliable. We have to pay closer attention to the wording and the context of the appelation 'pagan'. It is the letter from Grand Duke Casimir to the Teutonic Order requesting it to extradite his enemy Daumantas, who is characterised as 'such a pagan and the real enemy of the holy faith' (eyn sulcher heyde und echter [feind] des heiligen gelobens). ${ }^{68}$ The style and wording is intended to be readily comprehensible and provocative enough to move the Teutonic Order to take the 'right' course of action. It is clear that here 'pagan' is by no means a religiously correct ethnological description. It is opprobrium poured on one's political enemy. It must also be stressed that such an appelation is not unique in its character. The scriptoria related to Polish and Lithuanian affairs had in their propaganda arsenal the means to denigrate the 'other' as pagans. Perhaps the most conspicuous are cases in which the Ruthenians are called pagans, or are depicted as practising pagan rites (gentilium ritus). ${ }^{69} \mathrm{I}$ suppose that this evidence is enough to draw the conclusion that Daumantas was not a pagan.

${ }^{67}$ Cf. e.g. to our knowledge, it was only S.C. Rowell who voiced his reservation in this matter. See S.C. Rowell, 'Išdavystè ar paprasti nesutarimai? Kazimieras Jogailaitis ir Lietuvos diduomenè 1440-1481 metais', Lietuvos valstybe XII-XVIII a., ed. Z. Kiaupa, A. Mickevičius, J. Sarcevičienè (Vilnius, 1997), p. 49.

68 The emendation proposed by S.C. Rowell makes sense. The document in question has been preserved in Geheimes Staatsarchiv Preußischer Kulturbesitz. OBA 7923 (27 February, 1441). Published in Rowell, 'Išdavyste ar paprasti nesutarimai?', pp. 61-62.

${ }^{69}$ Cf. Drabina, Papiestwo-Polska, p. 28; Archivum Secretum Vaticanum. Registra Supplicum, vol. 144, f. 193-193v; Bullarium Poloniae litteras apostolicas aliaque monumenta Poloniae Vaticana continens, vol. 4: 1417-1431, ed. I. Sułkowska-Kuraś, S. Kuraś, H. Wajs (Rome-Lublin, 1992), no. 690 (the request by Ringaile, sister of Grand Duke Vytautas, for a divorce from her husband Alexander the Good, Prince of Moldavia, who was beholden, as it were, to the rites of the Gentiles! (1 July 1420). 
How religious was he? It is impossible to say. But the probable fact that he did manage some time to obtain from Kazimieras (or some other Grand Duke of Lithuania) a charter confirming his rights to certain lands favours the opinion that he belonged to the ranks of the Christian nobility. ${ }^{70} \mathrm{He}$ was not the last pagan Mohican in Žemaitija. In order to better understand what it could be like to be a 'pagan' in early Christian Lithuania, I have decided to make an excursus to the Bohemian missionary Jerome of Prague.

\section{The deceitfully pagan landscape of Jerome of Prague's mission}

It is assumed that the latest and probably the best eyewitness account of the pagan religion in late medieval Lithuania is furnished by the Camaldolese monk Jerome of Prague (c. 1369-c. 1440), who happened to be interviewed during the Council of Basle by no less a figure than Aeneas Silvius Piccolomini, the future pope Pius II. ${ }^{71}$ A visit to the monk, spending his last days in monastic tranquility on the Rhine, undertaken by so prominent a man and his friends was occasioned by their curiosity and disbelief in what others said about Jerome's missionary exploits in Lithuania under Vytautas. Jerome shared his reminiscences with his guests, who faithfully committed his account to writing. Upon his arrival in the country, Jerome had happened to meet people keeping and caring for grass-snakes in their houses. These had to be killed and burnt in public. After this first encounter, he came across a certain tribe that venerated a sacred fire burning in a temple looked after by priests (sacerdotes). They seem to have specialised in telling the future, during night seances in which they could tell whether a sick person would die or survive. Travelling further, he met another tribe, who venerated the sun and the unusually large iron hammer which had been put to good use by the signs of the Zodiac in their rescue action to liberate the sun from imprisonment by some powerful king. The 'priests'

${ }^{70}$ Cf. Saviščevas, Žemaitijos savivalda, p. 82.

71 The text, commentary and an exhaustive list of scholarly literature are published in Baltu religijos ir mitologijos šaltiniai, vol. 1, pp. 588-597. The report of Jerome of Prague was originally published in Aeneae Sylvii Piccolominei Historia rerum ubique gestarum (Venice, 1477). The most exhaustive recent treatment of this episode with references to literature has been produced by M. Bumblauskas, 'Jeronimo Prahiškio pasakojimas apie lietuvių religiją ir christianizaciją', Lietuvos istorijos studijos, vol. 28 (2011), pp. 24-43. 
around explained that it was only natural to venerate the instrument which was so important in restoring the light to mortals. On both counts, Jerome remained unimpressed. He persuaded the first tribe of their trickery, and demolished the temple and put out the fire. The worshippers of the sun were done away with by making a mockery of their 'stupid tale' and telling them that the sun, the moon and the stars had been created by God, who ordered them to shine for ever. Apparently, Jerome had more trouble over the task of felling holy groves, which were plentiful in the region he was travelling across. In this he was joined by some locals, who, after a few days of being exposed to preaching, were bold enough to approach holy trees, axe in hand. Eventually his zeal was reined in by Vytautas, who had been approached by a host of angry women complaining about Jerome for his destruction of the abode of God (sic!). Now they were left in the dark as to where they should look for God, who was driven out of his home, he was so necessary, the women implored him for fair weather. They were supported by men, who said that they too could not bear 'the new cult', and were much more ready to leave their motherland than to renounce their paternal faith. Being afraid, as it were, of a popular revolt, Vytautas revoked the missionary, and ordered him to leave the province. The moral of the story: Vytautas was much more ready to allow people to turn away from Jesus Christ than from himself.

This account by Jerome is generally viewed as a truthful reflection of pagan customs and practices. Many historians believe that the missionary had been in Žemaitija, some time in 1395-1398 or 1401-1404. As regards the locating of his activities in Žemaitija, there is no compelling reason to believe so. This idea is essentially based on the assumption of Žemaitija as a pagan land par excellence. It should be noted, however, that the account of Jerome throws a light showing that he travelled not just through domains subject to the rule of Vytautas; he was in an area where the protection of the local administration was sure, and where the writ of the grand duke carried its weight. This could not have been the case in Žemaitija at the turn of the 14th and 15th centuries. Some consideration must also be given to the fact that until the 1420 s, the status of Žemaitija in terms of ecclesiastical jurisdiction remained unsettled, so that is why it is highly improbable that a missionary could arrive there without special authorisation (of which there is quite naturally no trace left). Natural and formal difficulties were absent in those parts 
of (eastern) Lithuania that were subject to the direct rule of Vytautas and formed part of the Diocese of Vilnius. It is known that the first bishop of Vilnius had to travel and evangelise his neophyte flock for years after the formal conversion of the country in 1387. Naturally, he was not alone in this. Many other secular and regular clergymen were involved in this task. Therefore, it is natural to suppose that Jerome was one of them. What makes a difference is that simple but crucial circumstance: he remains alone in having had the good luck of being able to welcome such curious and such intelligent interviewers.

The absence of parallel testimonies from other missionaries makes it rather difficult to interpret the account of Jerome. It is trivial to say that this text is open to various interpretations, but this remark is necessary here, for one simple reason: we are not going to exhaust all possible interpretations, and engage in a debate about the cult of holy trees, fire and snakes. Rather, we would like to expose the idiosyncratic features of this account. Scholars generally view the landscape as it is reflected in the account of Jerome as heavily imbued with the hallmarks of a pristine heathen religion. This perspective has formed due to particular scholarly interests that focus on the reconstruction of the pre-Christian religion. The standpoint of Jerome offers, however, a slightly wider vista. For one, if he was travelling throughout a pagan landscape, why is there no talk of at least the need to bring heathen people to the baptismal font? It is clear that Jerome felt obliged to annihilate snakes, to fight against superstitions, to mock 'priests' for their naivity, and to preach to the people. However, is there no need to baptise them, and thus finally set them free from the power of the devil? In our opinion, this absence of the need for baptism stands in correlation to the absence of pagans, a standard phrase to describe non-baptised people. Had they already been baptised? If so, there was really no need to reiterate the rite. Did they cling to superstitious practices? If so, they could be bad Christians, but certainly not pagans. The account by Jerome provides no clear clue here. However, his statement that the women were missing God who was driven out of his home may more readily refer to the Christian God than to some pagan deity. It looks as if these women already had some tenets of the Christian faith: the Christian God was also the dispenser of good or bad weather. Next, it must be emphasised that after the destruction of the temple (whatever this could be), Jerome did not introduce the Christian 
faith as such; he just introduced Christian customs. However, it was only his own opinion that the customs before his arrival were bad, whether they were pagan there is no telling. Local people were quite satisfied with them. So the reaction of the people was quite natural: they became angry with Jerome because he wanted to introduce the 'new cult' and tried to force it on them. The dissatisfaction of this Christian zealot is almost heard in his concluding remark about Vytautas being ready to let people turn away from Jesus Christ for the sake of social order and stability. Nevertheless, it was only his own version of what the Christian way of life meant which could not gain currency in the world of peasants living far away from churches and close ecclesiastical supervision. As if by default, they were left to their own devices for much of the time.

So we tend to view the account by Jerome of Prague not so much as a description of the last pagan survivals, but rather as one of the earliest experiences missionaries had in rural areas in a newly converted country. We tend to view the 'pagan' priests that Jerome of Prague met in the course of his missionary peregrinations not as atavistic relics of bygone days, but as magicians and healers who were easy to find in the old Christian countries of Europe. ${ }^{72}$ The experience of Jerome of Prague was not a trip back in time, it was a trip into a fresh syncretism, which came about in the wake of the conversion of Lithuania, and was strong where churches and clergymen were quite a distance away. It is not surprising then that it is possible to find some parallels with the experiences of Jerome in later centuries. Maciej Stryjkowski has left a vivid description of how a Žemaitijan peasant in Kaunas reacted to the scene in which on Good Friday a Bernardine priest demonstrated how Jesus Christ was scourged. It was a real lesson, given not just by word of mouth. The priest used a rod and scourged a Crucifix. On seeing this, the peasant exclaimed: 'Who are you striking?' The priest responded: 'The Lord God.' The peasant again: 'Him, who gave us a bad harvest ("rye") last year?' The man next to him was quick to upstage the priest: 'That One.' 'Good, dear priest, go ahead, why did this God give us a bad harvest!' 73 There can be no doubt that this peasant was a Christian. Despite the fact that he lived more than a hundred years after the interlocutors of Jerome of Prague, his

72 R. Kieckheffer, Magic in the Middle Ages (Cambridge, 1990), pp. 56-64.

73 Baltu religijos ir mitologijos šaltiniai, vol. 2, p. 534. 
religious knowledge was hardly superior to that of the angry women missing their God in the wake of the heavy-handed performance by Jerome. As regards the experiences Jerome had with regard to snakes, he was one of the first to do battle with them, but he was far from the last. In remote provincial places, Jesuit missionaries and other foreigners happened to come across strange snake-like creatures with black fur and four legs living among the peasants as late as the 18 th century. ${ }^{74}$ To do battle against them required much the same exorcist's powers. This had to be undertaken during the Counter Reformation, when churches and clergymen were plentiful. The Jesuits managed to reach the fringes of society, where demonic powers were still very close to people. Jerome of Prague had ventured into the same places, and met a variety of religious phenomena, from the pagan-like cult of the snake to the Christianlike devotion to God.

Author Details

Dr Darius Baronas is a senior researcher in the Department of the History of the Grand Duchy of Lithuania at the Lithuanian Institute of History. His scholarly interests are the medieval history of Lithuania, with a special emphasis on Christianisation and international relations.

Address: Lithuanian Institute of History, Kražių 5, LT-01108 Vilnius

E-mail: baronas@istorija.lt

${ }^{74}$ A masterly analysis of this extraordinary phenomenon has been produced by V. Ališauskas, Sakymas ir rašymas: Kultūros modeliu tvermè ir kaita Lietuvos Didžiojoje Kunigaikštysteje (Vilnius, 2009), pp. 43-61. 


\section{References}

ALIŠAUSKAS, V. Sakymas ir rašymas: Kultūros modeliu tvermè ir kaita Lietuvos Didžiojoje Kunigaikštystèje (Vilnius, 2009).

ALMONAITIS, V. Žemaitijos politine padètis 1380-1410 (Kaunas, 1998).

ANDZIULYTĖ-RUGINIENĖ, M. Žemaičiu christianizacijos pradžia (Kaunas, 1937).

Baltu religijos ir mitologijos šaltiniai $=$ Sources of Baltic religion and mythology $=$ Quellen der baltischen Religion und Mythologie, vol. 2: XVI amžius, ed. N. Vèlius (Vilnius, 2001).

BARONAS, D. 'Die Flucht des litauischen Fürsten Kęstutis (Kynstut) aus der Marienburg 1361 und die Frage, ob der Deutsche Orden an seiner Gefangenschaft interessiert war', in Annaberger Annalen über Litauen und Deutsch-Litauischen Beziehungen, 12 (2004).

BARONAS, D. 'Die Hintergründe für Litauens späte Annahme des Christentums', in Annaberger Annalen über Litauen und Deutsch-Litauischen Beziehungen, 14 (2006).

BARONAS, D. 'Karalius krikščionis Mindaugas popiežiu akimis', in Mindaugas Karalius, ed. V. Ališauskas (Vilnius, 2008).

BARONAS, D. 'Katholisches und orthodoxes Litauen', in Lietuvos valstybès susikürimas europiniame kontekste, ed. R. Petrauskas (Vilnius, 2008).

BARONAS, D. 'Perkūno šventykla Vilniuje: senų mitų ir naujų mokslinių tyrimų nedermé', in Naujasis Židinys-Aidai, 7 (2012).

BARONAS, D. 'The Three Martyrs of Vilnius: a fourteenth-century martyrdom and its documentary sources', in Analecta Bollandiana, 1(122), (2004).

BARONAS, D. Trys Vilniaus kankiniai: istorija ir gyvenimas (istorine studija ir šaltiniai) = Tres martyres Vilnenses: Vita et historia (studium historicum et editio fontium) (Vilnius, 2000).

BARONAS, D. Vilniaus pranciškonu kankiniai ir ju kultas XIV-XX a. (Istorine studija ir šaltiniai) $=$ Fratres Minores Martyres Vilnenses Eorumque Cultus Saec. XIV-XX (studium historicum et editio fontium) [Studia franciscana lithuanica, vol. 4] (Vilnius, 2010).

BARONAS, D. 'Žemaičių krikštas Jono Dlugošo kronikos šviesoje', in Istorijos šaltiniu tyrimai, 3 (2011).

BARONAS, D. 'Drevneyshiye sledy prebyvaniya russkikh v Vil'nyuse', in Slavistica Vilnensis (=Kalbotyra), 2 (53) (2004).

BARONAS, D. et. al. Christianity in Lithuania (Vilnius, 2002).

BARONAS, D., ROWELL, S.C., The Conversion of Lithuania: from Pagan Barbarians to Late Medieval Christians (Vilnius, 2015).

BARTLETT, R. The Making of Europe: Conquest, Colonization and Cultural Change, 950-1350 (London, 1993). 
BLASCHKE, K., JÄSCHKE, U. Nikolaikirchen und Stadtenstehung in Europa: Von der Kaufmannssiedlung zur Stadt (Berlin, 2013).

BŁASZCZYK, G. Diecezja żmudzka od XV do początku XVII wieku. Uposażenie (Poznań, 1992).

BŁASZCZYK, G. Diecezja żmudzka od XV do początku XVII wieku. Ustrój (Poznań, 1993).

BŁASZCZYK, G. Dzieje stosunków polsko-litewskich od czasów najdawniejszych do współczesności, vol. 1: Trudne początki (Poznań, 1998).

BUMBLAUSKAS, M. 'Jeronimo Prahiškio pasakojimas apie lietuvių religiją ir christianizaciją', in Lietuvos istorijos studijos, 28 (2011).

CHODYNICKI, K. 'Próby zaprowadzenia chrześcijaństwa na Litwie przed r. 1386', in Przeglad historyczny, 18 (1914).

Christianization and the rise of Christian monarchy: Scandinavia, Central Europe and Rus' c. 900-1200, ed. by N. Berend (Cambridge, 2007).

Chrystianizacja Litwy, ed. J. Kłoczowski (Kraków, 1987).

Chrzest Litwy: Geneza, przebieg, konsekwencje, ed. M.T. Zahajkiewicz (Lublin, 1990).

COLKER, M.L. 'America rediscovered in the thirteenth century?', in Speculum, 54 (1979).

DRABINA, J. Papiestwo-Polska w latach 1384-1434 (Kraków, 2003).

DUBONIS, A. Traidenis: Monarcho valdžios atkūrimas Lietuvoje, (1268-1282) (Vilnius, 2009).

Dzieje chreścijaństwa na Litwie: Praca zbiorowa, ed. V. Ališauskas, translated by K. Korzeniewska (Warszawa, 2014).

FIJAŁEK, J. 'Uchrześcijanienie Litwy przez Polskę i zachowanie w niej języka ludu', in Polska i Litwa w dziejowym stosunku (Warsaw, etc., 1914).

FLETCHER, R. The Conversion of Europe: from Paganism to Christianity (London, 1998 repr.).

FREIBERGS, G. 'The Descripciones Terrarum: its date, sources, author and purpose', in Christianity in East-Central Europe, ed. by J. Kłoczowski, 2 (Lublin, 1999).

GIEDROYĆ, M. 'The arrival of Christianity in Lithuania: baptism and survival (1341-1387)', in Oxford Slavonic Papers, 22 (1989).

GIEDROYĆ, M. 'The arrival of Christianity in Lithuania: between Rome and Byzantium (1281-1341)', in Oxford Slavonic Papers, 20 (1987).

GIEDROYĆ, M. 'The arrival of Christianity in Lithuania: early contacts (thirteenth century)', in Oxford Slavonic Papers, 18 (1985).

GOLDFRANK, D.M. 'The Lithuanian Prince-Monk Vojšelk: a study of competeing legends', in Harvard Ukrainian Studies, 1-2 (11), (1987).

GÓRSKI, K. 'Descriptiones terrarum (Nowo odkryte źródło do dziejów Prus w XIII wieku)', in Zapiski Historyczne, 1 (46) (1981).

GRUBER, T. Die Polemik zwischen dem Deutschen Orden und PolenLitauen (1386-1422): Stationen-Argumente-Folge (München, 2010).

GUDAVIČIUS, E. Mindaugas (Vilnius, 1998). 
HAIN, S. 'Chrystianizacja Żmudzi', in Annales Missiologicae $=$ Roczniki Misjologiczne, 5 (1932-1933).

HELLMANN, M. 'Der Deutsche Orden und die Königskronung des Mindaugas', in Zeitschrift für Ostforschung, 3 (3), (1954).

IVINSKIS, Z. 'Mindaugas und seine Krone', in Zeitschrift für Ostforschung, 3 (3) (1954).

IVINSKIS, Z. Lietuvos istorija. Iki Vytauto Didžiojo mirties (Rome, 1978, n. e. Vilnius, 1991).

JAKŠTAS, J. 'Pavèluotas Lietuvos krikštas', in LKMA Suvažiavimo darbai, 6 (1969).

JURGINIS, J. Lietuvos krikštas: Feodalinès visuomenès socialinès ir kultūrinès raidos studija (Vilnius, 1987).

KIECKHEFFER, R. Magic in the Middle Ages (Cambridge, 1990).

Krikščionybès Lietuvoje istorija, ed. V. Ališauskas (Vilnius, 2006).

KURTYKA, J. 'Podole pomiędzy Polską i Litwą w XIV i 1. połowie XVwieku', in Kamieniec Podolski. Studia z dziejów miasta i regionu, ed. by F. Kiryk, 1 (2000).

La Cristianizzazione della Lituania. Atti del Colloquio internazionale di storia ecclesiastica in occasione del 6 centenario della Lituania cristiana (1387-1987). Roma, 24-26 giugno 1987, ed. P. Rabikauskas (Vatican City, 1989).

LIEDKE, M. 'Następstwa chrystianizacji Giedyminowiczów przed 1386 r.', in History, Culture and Language of Lithuania. Proceedings of the International Conference, Poznań 17-19 September 1998, ed. G. Błaszczyk, M. Hasiuk (Poznań, 2000).

Lietuvos istorija, Vol. 3: BARONAS, D., DUBONIS, A., PETRAUSKAS, R. XIII a. - 1385 m.: Valstybès iškilimas tarp Rytu ir Vakarų (Vilnius, 2011).

Lietuvos istorija, ed. A. Šapoka (Kaunas, 1936, n. e. 1989).

Lietuvos krikščionëjimas Vidurio Europos kontekste = Die Christianisierung Litauens im mitteleuropäischen Kontext, ed. V. Dolinskas (Vilnius, 2005).

ŁOWMIAŃSKI, H. Studja nad początkami społeczeństwa $i$ państwa litewskiego, 1-2 (Vilnius, 1931-1932).

Maironio raštai, vol. 4: Lietuvos praeitis. Ketvirtoji laida, žymiai perdirbta (Kaunas, 1926).

MCCORMICK, M. Eternal victory. Triumphal rulership in late antiquity, Byzantium, and the early medieval West (Cambridge, 1986).

NIKODEM, J. Witold wielki ksiązę litewski (1354 lub 1355 - 27 października 1430) (Kraków, 2013).

OCHMAŃSKI, J. 'Nieznany autor 'Opisu krajów' z drugiej połowy XIII wieku i jego wiadomości o Bałtach', in Lituano-Slavica Posnaniensia, 1 (1985). 
OCHMAŃSKI, J. Biskupstwo wileńskie $w$ średniowieczu: ustrój $i$ uposażenie (Poznań, 1972).

OCHMAŃSKI, J. Historia Litwy (Wrocław, etc., 1967).

PASHUTO, V.T. Obrazovanie litovskogo gosudarstva (Moscow, 1959).

PASZKIEWICZ, H. Jagiellonowie a Moskwa, vol. 1: Litwa a Moskwa w XIII i XIV wieku (Warsaw, 1933).

PREKOP, D. Wojna zakonu krzyżackiego z Litwa w latach 1283-1325 (Toruń, 2004).

RADOCH, M. Walki Zakony Krzyżackiego o Żmudź od połowy XIII wieku do 1411 roku (Olsztyn, 2011).

REKLAITIS, P. 'Die St. Nicolaikirche in Wilna und ihre stadtgeschichtliche Bedeutung', in Zeitschrift für Ostforschung, 4(8) (1959).

REMECAS, E., 'Vilniaus gaisro datavimo problematika: ar tikrai Vilniaus pilis sunaikino 1419 m. gaisras?', Lietuvos pilys, 6 (2010).

ROWELL, S.C. 'Išdavystè ar paprasti nesutarimai? Kazimieras Jogailaitis ir Lietuvos diduomenè 1440-1481 metais', in Lietuvos valstybe XII-XVIII a., ed. Z. Kiaupa, A. Mickevičius, J. Sarcevičienè (Vilnius, 1997).

ROWELL, S.C. 'Was Fifteenth-Century Lithuanian Catholicism as Lukewarm as Sixteenth-Century and Later Commentators Would Have Us Believe?', in Central Europe, 2(8) (2010).

ROWELL, S.C. 'Lithuania and the West, 1337-41. A Question of Sources', in Journal of Baltic Studies, 4(20) (1989).

ROWELL, S.C. 'Gediminaičių dinastinè politika Žemaitijoje 13501430’, in Žemaičiu praeitis, 3 (1994).

SAVIŠČEVAS, E. Žemaitijos savivalda ir valdžios elitas 1409-1566 metais (Vilnius, 2010).

STAKAUSKAS, J. Lietuva ir Vakaru Europa XIII a. (Vilnius, 2004, first edition 1934).

STAKAUSKAS, J. Lietuva ir Vakaru Europa XIII amžiuje (Kaunas, 1934, n. e. Vilnius, 2004).

STOPKA, K. 'Misja wewnętrzna na Litwie w czasach Mendoga a zagadnienie autorstwa 'Descriptiones terrarum', in Nasza Przeszłość, 68 (1987).

ŚWIEBODA, W. Innowiercy $w$ opiniach prawnych uczonych polskich w XV wieku: Poganie, żydzi, muzutmanie (Kraków, 2013).

URBAN, W. The Samogitian Crusade (Chicago, 1989).

VAITKEVIČIUS, G. Vilniaus įkūrimas (Vilnius, 2010).

VALANČIUS, M. Raštai, ed. B. Vanagienè, V. Merkys, 2 (Vilnius, 1972).

VĖLIUS, G. Kernavès miesto bendruomene XIII-XIV amžiuje (Vilnius, 2005).

WENTA, J. 'Do Goga z Magog. Głos w sprawie autorstwa "Descriptiones terrarum", in Droga historii. Studia ofiarowane Prof. Józefowi Szymańskiemu w 70 rocznice urodzin, ed. by P. Dymmel, K. Skupieński (Lublin, 2001). 
WRÓBLEWSKI, A. 'Chrystianizacja Litwy górnej', in Novum, 7-8 (1971)

ZABIELA, G. 'Laidosena pagoniškoje Lietuvoje', Lietuvos archeologija, 15 (1998).

Źródła do mytologii litewskiej, ed. A. Mierzyński, 1-2 (Warszawa, 1892-1896).

\section{KRIKŠČIONYS PASKUTINIAISIAIS PAGONIŠKOSIOS IR PAGONYS PIRMAISIAIS KRIKŠČIONIŠKOSIOS LIETUVOS LAIKAIS: XIV-XV AMŽIAI}

Santrauka

\section{DARIUS BARONAS}

Šiame straipsnyje nagrinėjama krikščionių padètis pagoniškoje Lietuvoje ir pagonių padėtis krikščioniškosios Lietuvos pirmaisiais metais (iš esmès iki Žemaitijos krikšto, vykusio 1413-1417 m.). Nagrinejjant ši klausimą, būtinas bendresnis Lietuvos christianizacijos (XIII-XV a.) kontekstas, todèl straipsnyje paliečiami atitinkami ìvykiai ir procesai. Autorius siūlo remtis grupinės analizès metodu, kuris leistų atskleisti atskirų Lietuvos kunigaikščių ir jų aplinkos žmonių darytą ịtaką tiek ,ilgai“ išlaikant pagonybę, tiek neskausmingai priimant naujaji krikščionių tikèjimą. Tokia eiga leidžia stebèti, kaip palaipsniui pačioje valdovų giminèje plètèsi krikščionybės įtaka, galiausiai beveik natūraliai persvèrusi ir pakeitusi pagoniškajị paveldą, kuris dar iki oficialaus Lietuvos krikšto jau buvo gerokai išsikvėpęs. Autoriaus manymu, ,gyvenimo būdo“ diktuojami apsisprendimai gali kur kas geriau paaiškinti krikščionybès prièmimo/neprièmimo dilemą negu didžiujų politikos įvykių ir procesų analizè, kuri yra daugelio istorikų „duona kasdieninë“. Todèl krikščionių tikejjimo prièmimą, ịvykusị Lietuvoje XIV a. pabaigoje, derètų aiškinti ne tik, o galbūt ir ne tiek, politikos kūrimo ypatybėmis, kiek tuo, kad tuo metu prie valstybės vairo stojo nauja valdovų (Jogailos ir Vytauto) karta, kuri nuo savo tèvų skyrėsi mentalitetu. Šio virsmo požiūriu svarbi yra krikščionių egzistencija pagoniškoje Lietuvoje, visų pirma Vilniuje ir Kernavejje. Manytina, kad būtent šie žmonès prisidejjo prie to, kad krikščioniškasis pasirinkimas buvo ne tik priimtas, bet ir be didesnių sukrètimų igyvendintas (autoriaus manymu, Dlugošo tapomi pagonių šventyklos Vilniuje griovimo ir stabų daužymo vaizdai yra veikiau literatūrinès išmonès, bet ne realiai $1387 \mathrm{~m}$. nutikusių 
ịvykių atspindžiai). Autorius siūlo pagonis visų pirma suvokti kaip nekrikštytus žmones. Tačiau vadinti „pagonimis“ žmones, kuriuos sutiko savo misijos Lietuvoje metu Jeronimas Prahiškis, yra ne visai adekvatu. Šio misionieriaus patirtis Lietuvoje siūloma vertinti ne kaip susidūrimą su „grynaja“" pagonybe, o kaip patekimą ị sinkretinę aplinką, kuriai uolusis misionierius turejjo daug priekaištų. 